\title{
Isotype-dependent pathogenicity of autoantibodies: analysis in experimental autoimmune hemolytic anemia
}

\author{
Shozo Izui, Liliane Fossati-Jimack, Samareh Azeredo da Silveira, Thomas Moll \\ Department of Pathology, University of Geneva, Geneva, Switzerland
}

\section{Introduction}

Autoantibodies are the essential factors for several clinical manifestations associated with a number of autoimmune diseases. The direct binding of certain autoantibodies such as anti-erythrocyte and anti-platelet autoantibodies to their targets can cause autoimmune cellular damage. Other autoantibodies such as anti-DNA autoantibodies can provoke tissue lesions as a result of their deposition in renal glomeruli and small vessels. However, because of the occasional lack of correlation between elevated serum levels of autoantibodies and clinical manifestations, it has long been suggested that only a subset of autoantibodies generated during the course of autoimmune diseases is indeed pathogenic, and that the qualitative aspects of autoantibodies are important for the pathogenesis of autoantibody-mediated cellular and tissue injuries.

The structure of the Fab region defines the specificity and affinity with which autoantibodies bind to self-antigen, and these characteristics are clearly of primary importance for pathogenic activities. In addition, the Fc region is also likely to play a critical role in autoantibody pathogenicity by activating IgG FC-receptor(Fc $\gamma \mathrm{R}$ )-bearing effector cells, by activating the complement cascade and by inducing IgM multivalency-dependent agglutination of target cells. Thus, the pathogenic potential of autoantibodies is most straightforwardly attributable to the combined action of the selfantigen-binding properties of the Fab region and the effector functions associated with the $\mathrm{Fc}$ region of the different immunoglobulin $(\mathrm{Ig})$ isotypes. Therefore, it is conceivable that a change of $\mathrm{Ig}$ isotype may result in a remarkable change in the pathogenic potential of autoantibodies, because Ig class switching can alter Fc-dependent effector functions and can be accompanied by concomitant changes in autoantibody affinity (affinity maturation). Until recently this question has not been directly studied, because of the lack of suitable experimental models that easily reproduce some of the main pathological manifestations observed in autoimmune diseases. 
For this reason, we have recently assessed the pathogenic activity of murine antierythrocyte monoclonal autoantibodies derived from autoimmune-prone NZB mice. This experimental system presents several advantages. First, the binding of the antired blood cell (anti-RBC) autoantibodies in vivo, i.e., the presence of opsonized $\mathrm{RBC}$, can be easily monitored by flow-cytometric analysis of circulating RBC after injection of anti-RBC autoantibodies into mice. Second, the pathogenic effect of the anti-RBC autoantibodies, i.e., the development of anemia, can be followed by a simple measurement of hematocrit values. Finally, the histological analysis of spleen and liver can identify the pathogenic mechanisms of anemia, and its severity can be evaluated by analyzing the extent of erythrophagocytosis by Kupffer cells in the liver. In this article, we will discuss the molecular and cellular basis for pathogenic activities of anti-RBC autoantibodies with regard to their specificity and RBC-binding affinity, as well as the effector functions associated with the $\mathrm{Fc}$ region of the different Ig isotypes.

\section{Autoimmune hemolytic anemia in NZB mice}

NZB mice spontaneously develop autoimmune hemolytic anemia as a result of production of Coombs' autoantibodies reacting with their own RBC [26]. Although the molecular nature of the target autoantigens responsible for the induction of this autoimmune response has not been well characterized, the fact that autoantibodies eluted from RBC of Coombs-positive NZB mice react only with mouse RBC but not with RBC from various other species [30] has suggested the importance of the specificity of these autoantibodies for their pathogenicity. A more detailed analysis of a panel of anti-RBC monoclonal antibodies ( $\mathrm{mAb}$ ) derived from NZB mice has shown that the pathogenic autoantibodies capable of inducing anemia recognize only species-specific antigens on mouse RBC, while non-pathogenic autoantibodies cross-react with determinants present on RBC from many different species $[9,48]$. The importance of the anti-mouse $\mathrm{RBC}$ specificity is further documented by the finding that, among five different IgM anti-RBC mAb, only the three pathogenic mAb (4C8, IE 10 and G8) are capable of inducing a marked hemagglutination, which is responsible for the development of anemia by this isotype. It may be that the surface density of antigenic determinants recognized by non-pathogenic IgM autoantibodies is too low to promote agglutination of mouse RBC in vivo. Thus, differences in the distribution and the nature of target antigens likely account for the difference in the pathogenic activities of these IgM anti-RBC mAb.

The specificity of these autoantibodies reacting with exposed surface determinants of intact RBC is distinct from that of another category of erythrocyte autoantibodies which react with a cryptic surface antigen disclosed after proteolytic treatment with bromelain [30]. However, none of the autoantibodies specific for bromelain-treated mouse RBC (BrMRBC) is able to induce anemia, excluding the possibility that they play a primary role in the immune destruction of intact $\mathrm{RBC}$, causing anemia. It is, however, possible that pathogenic anti-RBC autoantibodies may damage the RBC membrane sufficiently to expose the cryptic antigens, and consequently, anti-BrMRBC autoantibodies may additionally contribute to the hemolytic process [8]. Alternatively, these antibodies may represent physiological constituents of serum, serving as transporters of catabolic products, as proposed by Grabar [22], as they are detectable at significant levels in non-autoimmune mice. 
High pathogenic potential of low-affinity anti-RBC autoantibodies promoting efficient Ig-isotype-dependent effector functions

It has long been believed that the high-affinity binding of autoantibodies to self-antigens is critical for the expression of their pathogenic activities in vivo. This notion has been supported by the demonstration that the affinity maturation of autoantibodies resulting from somatic hypermutations in the $\mathrm{Ig}$ genes in association with $\operatorname{IgM}$ to IgG class switching coincides with progression of the clinical development of autoimmune diseases such as systemic lupus erythematosus $[24,49,57]$. However, somatic hypermutations do not always result in affinity maturation of autoantibodies, as observed in clonally related anti-IgG2a rheumatoid factors isolated from an autoimmune-prone MRL-lpr/lpr mouse [29]. More significantly, it has been shown that a low-affinity anti-IgG2a rheumatoid factor is able to induce lupus-like glomerulonephritis and immune-complex-mediated vasculitis when provided with a cryoglobulin activity uniquely associated with murine IgG3 isotype [20]. Thus, it is possible that low-affinity anti-RBC autoantibodies could become highly pathogenic, if combined with appropriate $\mathrm{Fc}$-dependent effector functions of a given lg isotype.

In fact, the analysis of an IgG2a class-switch variant of $4 \mathrm{C} 8 \mathrm{IgM}$ anti-RBC mAb reveals its high pathogenicity despite its low-affinity binding to mouse RBC (Table 1). The low-affinity feature of the $4 \mathrm{C} 8 \mathrm{mAb}$ is documented by a markedly limited RBCbinding activity of the $4 \mathrm{C} 8 \mathrm{IgG} 2 \mathrm{a}$ variant, 1,000 times lower than that of a high-affinity 34-3C IgG2a mAb [19]. As expected, opsonized RBC is hardly detectable in the circulating blood from mice injected with even $1 \mathrm{mg} \mathrm{4C8} \operatorname{lgG} 2 \mathrm{a}$, in marked contrast to the presence of bound antibodies on circulating $\mathrm{RBC}$ following the injection of as little as $1 \mathrm{Hg} 34-3 \mathrm{C}$ IgG2a mAb [19]. Nevertheless, to our surprise, the $4 \mathrm{C} 8$ IgG2a variant with low binding affinity was able to induce a severe anemia as at result of FcyR-mediated erythrophagocytosis by hepatic Kupffer cells. This indicates that a remarkably efficient ability of the IgG2a isotype to interact with FcyR renders even low-affinity anti-RBC autoantibodies highly pathogenic. Most strikingly, the amount of the low-affinity $4 \mathrm{C} 8 \mathrm{IgG} 2 \mathrm{a}$ variant required to induce anemia, despite a more than 1,000 times weaker RBC-binding activity, is comparable to that of the high-affinity 34-3C IgG2a mAb (Table 1). Thus, RBC-binding affinities of Coombs'

Table 1. Pathogenic activities of low-aftinity $4 \mathrm{C} 8$ Ig class-switch variants in comparison with those of bigh-affinity $34-3 \mathrm{C}$ and $105-2 \mathrm{H} \mathrm{mAb}$ in autoimmune hemolytic anemia. The original isotype of the mAb isolated from NZB mice [48] is in roman type, while genetically produced switch variants are in italjcs. The anemic dose is the quantity of $\mathrm{mAb}$ required for inducing anemia, where hematocrit values below $40 \%$ are considered as anemic

\begin{tabular}{|c|c|c|c|c|}
\hline $\mathrm{mAb}$ & Affinity & Isotype & Anemic dose $(\mu g)$ & Pathogenicity \\
\hline $4 C 8$ & Low & $\begin{array}{l}\operatorname{IgM} \\
\lg G 2 a \\
\lg G I \\
\lg G 2 b \\
\lg G 3\end{array}$ & $\begin{array}{l}50 \mu \mathrm{g} \\
50 \mu \mathrm{g} \\
1000 \mu \mathrm{g} \\
5000 \mu \mathrm{g} \\
\end{array}$ & $\begin{array}{l}\text { High } \\
\text { High } \\
\text { Intermediate } \\
\text { Low } \\
\text { None }\end{array}$ \\
\hline $34-3 C$ & High & $\begin{array}{l}\operatorname{IgG} 2 \mathrm{a} \\
\operatorname{Ig} G I\end{array}$ & $\begin{array}{l}25 \mu \mathrm{g} \\
500 \mu \mathrm{g}\end{array}$ & $\begin{array}{l}\text { High } \\
\text { Intermediate }\end{array}$ \\
\hline $105-2 \mathrm{H}$ & High & $\mathrm{IgGl}$ & $500 \mu \mathrm{g}$ & Intermediate \\
\hline
\end{tabular}


autoantibodies apparently play a relatively minor role in the in vivo hemolytic activities of the IgG2a isotype.

It is, however, worth noting that when the pathogenic activities are compared in mice receiving higher doses of these two IgG2a anti-RBC mAb, the $34-3 \mathrm{C} \mathrm{mAb}$ is clearly more pathogenic than the 4C8 IgG2a mAb [19]. This may be related in part to differential usage of two different classes of FcyR, high-affinity FcyRI and low-affinity FcyRIII, involved in erythrophagocytosis. In fact, we have observed that both FcyRI and FcyRIII contribute to the development of anemia induced by a high dose $(200 \mu \mathrm{g})$ of the $34-3 \mathrm{C} \mathrm{IgG2a} \mathrm{mAb}$, while only the low-affinity FcyRIII is implicated in anemia provoked with the same amount of the $4 \mathrm{C} 8 \operatorname{IgG} 2 \mathrm{a}$ mAb [18]. This suggests that the contribution of the high-affinity $\mathrm{F} c \gamma \mathrm{RI}$ to Kupffer-cell-mediated erythrophagocytosis is more dependent on the antigen-binding affinity of the IgG2a antiRBC autoantibody. The usage of FcyRI by phagocytes is apparently limited in vivo because of the competition between IgG2a autoantibody bound to RBC and excess amounts of monomeric, unbound IgG2a having a high-affinity interaction with FcyRI [60]. However, highly increased densities of the 34-3C IgG2a bound on RBC could efficiently compete with circulating monomeric $\operatorname{IgG} 2 \mathrm{a}$ for the binding to FcyRI on phagocytes, thereby promoting erythrophagocytosis and hence accelerating the development of anemia. On the other hand, this is not the case for the binding to the low-affinity Fc $\gamma R$ RII, which lacks significant affinity to monomeric IgG2a. In addition, markedly opsonized $\mathrm{RBC}$ in mice receiving higher doses of the $34-3 \mathrm{C} \mathrm{mAb}$ could efficiently activate complement, thereby aggravating hemolytic anemia. In fact, this has been supported by our recent finding that the injection of $200 \mu \mathrm{g} \mathrm{34-3C}$ IgG2a, but not 4C8 IgG2a, induces a significant anemia in mice lacking both phagocytic Fc $\gamma R$ I and FcyRIII (unpublished observation). Thus, an enhanced pathogenicity of the high-affinity $34-3 \mathrm{C} \mathrm{mAb}$ at higher doses, as compared with the low-affinity $4 \mathrm{C} 8 \mathrm{IgG2a} \mathrm{mAb}$, is likely due to the combined effect of a more efficient interaction with the high-affinity FcyRI and a more efficient activation of the complement system.

It should also be stressed that the pathogenic potential of the low-affinity $4 \mathrm{C} 8$ IgGl variant is almost comparable to that of the high-affinity $105-2 \mathrm{H} \mathrm{IgGl}$ and an IgGl switch variant of the high-affinity 34-3C mAb (Table 1), all of which induce anemia through the activation of FcyR-dependent erythrophagocytosis [18, 31]. However, $\operatorname{lgG} 2 \mathrm{~b}$ and $\operatorname{IgG} 3$ class-switch variants of the $4 \mathrm{C} 8 \mathrm{mAb}$ are poorly pathogenic, because of limited interaction of these isotypes with FcyR (Tables 1,2). This clearly indicates that the pathogenic activity of low-affinity IgG anti-RBC autoantibodies is dramatically enhanced, if combined with an appropriate Ig heavy-chain effector function, namely the capacity to interact efficiently with Fcy $R$ involved in erythrophagocytosis. However, it is still possible that high-affinity anti-RBC autoantibodies of IgG2b and IgG3 isotypes could become more pathogenic, owing to their enhanced interaction with FcyR and/or activation of complement as a result of a markedly increased opsonization, as compared with their low-affinity counterparts.

In addition to the remarkable contribution of the $\mathrm{IgG} \mathrm{Fc}$ region to the pathogenic activities of the low-affinity 4C8 IgG2a variant, it is worth noting that the low-affinity $4 \mathrm{C} 8 \mathrm{IgM}$ isotype is also highly pathogenic to an extent comparable to that of its IgG2a variant and the high-affinity $34-3 \mathrm{C} \operatorname{IgG} 2 \mathrm{a}$ mAb (Table 1). The strong pathogenic activity of the $4 \mathrm{C} 8 \mathrm{IgM}$ isotype is dependent on its pentameric form, since it promotes a high-avidity binding, which is more than 1,000 times stronger than that of its IgG2a variant and comparable to that of the 34-3C IgG2a mAb [19], and induc- 
es the agglutination of RBC in vivo [48]. Consequently, the IgM isotype of the 4C8 $\mathrm{mAb}$ induces a different form of anemia, resulting from massive agglutination of $\mathrm{RBC}$ in spleen and liver, which does not involve FcyR-mediated phagocytosis and complement activation $[12,48]$. The importance of the pentameric form of $\operatorname{IgM}$ for the in vivo agglutination of $\mathrm{RBC}$ is further supported by the finding that an IgG3 variant of the $4 \mathrm{C} 8 \mathrm{mAb}$, which is unable to mediate $\mathrm{Fc} \gamma \mathrm{R}$-dependent erythrophagocytosis, fails to induce agglutination of RBC in vivo [18].

The demonstration of the high pathogenic potency of low-affinity autoantibodies suggests that the affinity maturation of autoantibodies may not necessarily be a critical process for the generation of autoantibodies with immunopathological consequences. It has also been shown that a low-affinity anti-IgG2a rheumatoid factor of IgG3 isotype is able to induce lupus-like glomerulonephritis and immune-complexmediated skin vasculitis, owing to the IgG3-dependent cryoglobulin activity [20]. These results provide new insight into the cellular basis of the generation of pathogenic autoantibodies. It has already been shown that a fraction of $\mathrm{B}$ cells expressing the low-affinity $4 \mathrm{C} 8$ autoantibody can escape clonal deletion in the bone marrow and can be activated to produce pathogenic autoantibodies in the periphery, as a result of nonspecific $B$ cell activation $[33,34]$. These autoantibodies may even be switched to IgG classes under certain conditions, possibly through the action of cytokines and independently of the presence of autoantigen-specific $T$ helper cells, as in the case of T-independent type II immune responses [50]. Genetic abnormalities present in certain autoimmune-prone mice may favor the switching of $\operatorname{IgM}$ to $\operatorname{IgG}$ isotypes, as shown by a spontaneous class switch from $\operatorname{lgM}$ to $\operatorname{IgG} 2$ a autoantibody in B cells derived from lupus-prone ( $\mathrm{NZB} \times \mathrm{NZW}) \mathrm{Fl}$ mice in the absence of functional $\mathrm{CD}^{+} \mathrm{T}$ helper cells $[42,43]$. It has been hypothesized that autoreactive $B$ cells can be generated as a result of somatic hypermutations in the germinal centers during immune responses against environmental antigens, and that such B cells may persist, if they are defective in the process of apoptosis, which is likely to be one of the genetic defects present in autoimmune-prone mice $[13,58]$. This suggests that pathogenic autoantibodies can be generated at least partly by a mechanism that is independent of the activation of autoreactive $B$ cells by autoreactive $T$ helper cells and self-antigens.

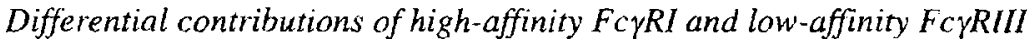 to IgG-isotype-dependent anti-RBC pathogenicity}

An initial analysis of pathogenic anti-RBC $\mathrm{mAb}$ bearing different $\mathrm{Ig}$ isotypes has shown that complement activation plays a minimal role in the development of anemia [48]. In contrast, Fc $\gamma$ R-mediated erythrophagocytosis by $\operatorname{IgG}$ anti-RBC mAb and splenic and hepatic sequestration of RBC agglutinated by IgM anti-RBC mAb have been recognized as the major pathogenic mechanisms responsible for autoimmune hemolytic anemia in mice $[12,31,48]$. Murine phagocytic cells express two different classes of phagocytic Fc $\gamma R$ : the high-affinity FcyRI and the low-affinity FcyRIII (for reviews, see $[27,37,39]$ ). The high-affinity FcyRI is capable of binding monomeric IgG2a [60], while the low-affinity FcyRIIl binds polymeric forms of different IgG isotypes except IgG3 [62]. Both FcyR are hetero-oligomeric complexes, in which the respective ligand-binding $\alpha$ chains are associated with the common $\gamma$ chain, which is

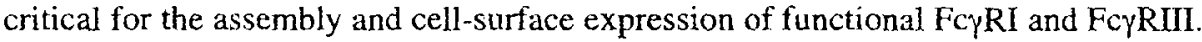
The FcR y chain carries a cytoplasmic ITAM (immunoreceptor tyrosine-based acti- 
Table 2. Pathogenic activities of the $4 \mathrm{C} 8 \mathrm{Ig}$ class-switch variants, respective contributions of FCYRI and FcyRIII to the development of $4 \mathrm{C} 8$-induced anemia, and their relative affinities to polymeric forms of the four IgG isotypes. The relative pathogenic activity of individual Ig isotypes of the $4 \mathrm{C} 8$ anti-RBC mAb is expressed as a percentage of the capacity of the $4 \mathrm{C} 8 \operatorname{IgM} \mathrm{mAb}$ to induce anemia (Table 1). The relative in vivo affinity of Fc $\gamma \mathrm{RI}$ and FcyRIII to polymeric forms of the four different IgG isotypes is arbitrarily graded on the basis of in vivo evidence for erythrophagocytosis by Kupffer cells in the liver of different Fcy $R$ deficient mice

\begin{tabular}{|c|c|c|c|c|}
\hline \multirow[t]{2}{*}{ Isotype } & \multirow[t]{2}{*}{ Pathogenicity (\%) } & \multirow[t]{2}{*}{ FcyR contribution } & \multicolumn{2}{|c|}{ Affinity of } \\
\hline & & & FcyRI & FcyRilI \\
\hline $\operatorname{IgM}$ & 100 & - & - & - \\
\hline IgGl & 5 & FcyRIII & - & ++ \\
\hline $\operatorname{IgG} 2 \mathrm{a}$ & 100 & FcyRIII>FcyRI & ++ & +++ \\
\hline $\operatorname{IgG} 2 b$ & 1 & FcyRIII/FcyRI & + & + \\
\hline $\operatorname{IgG} 3$ & 0 & - & - & - \\
\hline
\end{tabular}

vation motif) sequence required for the recruitment and activation of the Src and Syk family of protein tyrosine kinases [15]. Thus, the FcR $\gamma$ chain is an essential component for the triggering of various effector functions of both FcyRI and Fc $\gamma$ RIII, including phagocytosis by macrophages, degranulation by mast cells and antibody-dependent cell-mediated cytotoxicity by natural killer cells [54].

The in vivo pathogenicity of anti-RBC autoantibodies of different $\operatorname{lgG}$ isotypes may be critically dependent on the relative affinities of Fc $\gamma R I$ and FcyRIII to the polymeric form of each IgG isotype, in view of the major role of FcyR-mediated erythrophagocytosis in the pathogenesis of autoimmune hemolytic anemia $[12,31$, 48]. This question has been recently addressed by assessing the pathogenic potency of four different IgG class-switch variants (IgG1, IgG2a, IgG2b and IgG3) of the low-affinity $4 \mathrm{C} 8$ anti-RBC mAb in relation to their utilization of the two classes of phagocytic FcyR [18]. Our analysis has demonstrated that the four IgG isotypes of this autoantibody display striking differences in pathogenicity. The IgG2a isotype exhibits the highest pathogenicity, approximately 20 - and 100 -fold more potent than that of its $\operatorname{IgGl}$ and $\mathrm{IgG} 2 \mathrm{~b}$ variants respectively, while the $\mathrm{IgG} 3$ variant is not pathogenic at all (Tables 1,2). These differences are apparently determined by the capacity of individual IgG isotypes to interact in vivo with FcyRI and Fc $\gamma$ RIII. In fact, the IgG2a isotype interacts most efficiently with both FcyRI and FcyRIII, the IgG1 isotype binds only with the low-affinity FcyRIII, and the IgG2b isotype apparently interacts only weakly with both receptors (Table 2 ). In contrast, the $\operatorname{IgG} 3$ isotype displays little interaction with these phagocytic $\mathrm{Fc} \gamma \mathrm{R}$.

The complete dependence of the 4C8 IgGl-mediated erythrophagocytosis on FcyRIII is consistent with the results obtained with the 105-2H IgG1 anti-RBC mAb [31] and 34-3C IgG1 switch variant (unpublished observation). On the basis of in vitro studies using macrophages or transfected cell lines, it has been proposed that FcyRIII has a comparable affinity to IgG1, IgG2a and IgG2b, but little affinity to IgG3 [23, 62]. However, our in vivo analysis in different FcyR-deficient mice has clearly demonstrated marked differences in the relative affinity of FcyRIII to these three IgG isotypes; highest for IgG2a, intermediate for IgG1 and lowest for IgG2b, which directly reflects the different pathogenicity of these different IgG isotypes (Table 2). 
It is striking to observe that mice lacking Fc $\gamma$ RIII are totally resistant to the pathogenic effect of lower doses $(50-200 \mu \mathrm{g})$ of the $4 \mathrm{C} 8 \mathrm{IgG} 2 \mathrm{a}$ variant, while FcyRI additionally contributes to $\operatorname{IgG} 2 \mathrm{a}$-dependent erythrophagocytosis only when higher doses (above $1 \mathrm{mg}$ ) of the anti-RBC mAb are injected [18]. This indicates that FcyRIII plays a major role in the $4 \mathrm{C} 8$-IgG2a-induced anemia, which is also the case for anemia induced by the $34-3 \mathrm{C} \mathrm{IgG2a} \mathrm{mAb}$. This demonstration is somehow unexpected, since it has been thought that IgG2a immune complexes preferentially interact with FcyRI because of its high-binding affinity to the IgG2a isotype [60]. However, as discussed above, a limited utilization of FcyRI for phagocytosis of IgG2a-opsonized $\mathrm{RBC}$, due to competition with excess amounts of circulating monomeric IgG2a, could explain this observation. In fact, our recent demonstration of an enhanced utilization of FcyRI in IgG2a-dependent erythrophagocytosis in $\lg$-deficient mice confirms this idea (manuscript in preparation).

It has long been believed that the IgG2b isotype is unable to interact with the high-affinity FcyRI [28]. However, studies with the $4 \mathrm{C} 8 \mathrm{IgG} 2 \mathrm{~b}$ variant reveal that $\mathrm{Fc} \gamma \mathrm{RI}$ apparently has a significant affinity to IgG2b immune complexes, though much lower than that to IgG2a immune complexes [18]. This conclusion is drawn from the observation that $4 \mathrm{C} 8$-IgG2b-dependent erythrophagocytosis by Kupffer cells is little affected by the absence of either FcyRI or FcyRIII, but completely protected in FcR $\gamma$-deficient mice lacking both FcyRI and FcyRIII, indicating a significant contribution of Fc $\gamma R I$ as well as FcyRIII to IgG2b-induced autoimmune hemolytic anemia (Table 2). Notably similar results are obtained with in vitro studies using peritoneal macrophages isolated from mice deficient in FcyRI and/or FcrRIII. Therefore, the lack of detectable binding of lgG2b-opsonized RBC to FcyRI in previous studies may be in part related to the fact that these results were obtained by using COS cells transfected with FcyRI $\alpha$ cDNA, thereby expressing Fc $\gamma R I$ a chains but not $\gamma$ chains $[17,28]$. Thus, the "FcyRI" expressed on those transfected cells do not appear to behave like the native receptors, the expression of which on phagocytic effector cells is totally dependent on FcR $\gamma$ chains [54]. In fact, the affinity of the "FcyRI" expressed on COS cells is 2- to 5-fold lower than that of the native FcyRI [32], which would explain the lack of binding of IgG2b-opsonized RBC to the "Fc $\gamma \mathrm{RI}$ ", because of a weak binding affinity of Fc $\gamma \mathrm{RI}$ to IgG2b immune complexes.

It has been controversial whether there exists any receptor for murine IgG3 isotype. Diamond and Yelton proposed some time ago that a new, previously unidentified IgG3-specific phagocytic Fc $\gamma \mathrm{R}$ might be expressed on macrophages [16]. More recently, following work using bone-marrow-derived macrophages from FcyRI-deficient mice, Fc $\gamma R I$ has been claimed to be the sole receptor for the IgG3 isotype [21]. However, the complete absence of erythrophagocytosis by Kupffer cells in mice, even after the implantation of 4C8-IgG3-secreting cells, argues against any significant affinity of both FcyRI and FcyRIII to murine IgG3 isotype in vivo [18]. One should nevertheless consider that RBC are very poorly opsonized by the $4 \mathrm{C} 8 \mathrm{IgG3}$ variant, and that the affinity, if any, of FcyRI for the IgG3 isotype is apparently lower than that for the $\operatorname{IgG} 2 \mathrm{a}$ isotype [21]. Therefore, one cannot exclude the possibility that the interaction of FcyRI with a limited amount of the $4 \mathrm{C} 8 \mathrm{IgG} 3 \mathrm{mAb}$ present on $R B C$ can be readily interfered with by an excess of circulating monomeric IgG2a. However, the finding that a high-affinity IgG3 mAb against cryptococcal capsular polysaccharide also fails to provoke phagocytosis through both FcyRI and FcyRIII in vitro and in vivo [63] strongly argues against this possibility, further supporting the lack of interaction of Fc $\gamma R I$ and FcyRIII with the IgG3 isotype. 
Lack of contribution of the inhibitory FC $\gamma R I I B$ to autoimmune hemolytic anemia

Murine phagocytic effector cells express an additional $F c \gamma R, F c \gamma R I I B$, which is a single $\alpha$ chain receptor, in which the extracellular domain is highly homologous with its activatory counterpart, while its cytoplasmic domain contains the inhibitory ITIM (immunoreceptor tyrosine-based inhibition motif) sequence [2]. Upon coligation of the inhibitory Fc $\gamma R$ to an ITAM containing activatory $F c \gamma R$, cell activation is inhibited by the recruitment of an inositol-polyphosphate phosphatase, SHIP, which mediates the inhibition of calcium flux [35]. Murine FcyRIIB exist in two major isoforms, FcyRIIB 1 and Fc $\gamma R$ IIB2 [40]. The B1 isoform is not efficiently internalized upon binding of IgG immune complexes, because of the presence of a 47-amino-acid insertion in the cytoplasmic region, but mediates inhibition of $B$ cell activation after coligation with the B cell antigen receptor (BCR) [2]. In contrast, the FcyRIrB2 isoform is capable of promoting the endocytosis of IgG immune complexes, thereby facilitating antigen processing and presentation by macrophages [2]. Nevertheless, the complete dependence of erythrophagocytosis on Fc $\gamma R I$ and/or FcyRIII, as observed in studies with different $4 \mathrm{C} 8 \mathrm{IgG}$ class-switch variants, clearly indicates a lack of phagocytosis-inducing capacity of Fc $\gamma$ RIIB [18].

It has been demonstrated that FcyRIIB-deficient mice exhibit higher humoral anaphylactic and inflammatory immune responses, which underlines the importance

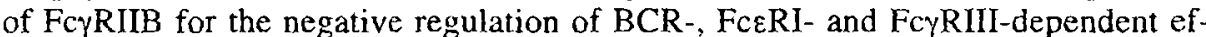
fector functions in vivo $[11,46,55,59]$. However, we have recently shown that FcyRIIB is unable to down-regulate FcyRI- and FcyRIII-mediated phagocytosis of RBC opsonized with 34-3C IgG2a (unpublished observation) or 105-2H IgGl anti$\mathrm{RBC} \mathrm{mAb}$ in vivo [46]. In this regard, it is somehow unexpected that the development of immune thrombocytopenia induced by an IgG2a anti-platelet mAb is apparently down-regulated by FcyRIIB [44]. This may raise the possibility that the development of thrombocytopenia following the injection of IgG2a anti-platelet autoantibodies may be mediated not only by FcyR-mediated phagocytosis but also by another mechanism as a consequence of FcyR-triggered activation of macrophages. This latter process may be efficiently counter-regulated by the co-engagement of Fc $\gamma$ RIIB, while it is not relevant to the development of autoimmune hemolytic anemia.

\section{Possible role of complement in autoimmune hemolytic anemia}

The complement components interact most efficiently with mouse IgM immune complexes and to a lesser extent with IgG2a immune complexes, which trigger the classical pathway of complement activation by binding of $\mathrm{Clq}$. Therefore, it is somehow surprising to see that none of the anti-RBC mAb, even of the IgM isotype, is able to induce hemolysis of mouse $\mathrm{RBC}$ in vitro in the presence of complement from any species [48]. In addition, the development of anemia induced by $4 \mathrm{C} 8 \mathrm{IgM}$ and $34-3 \mathrm{C} \mathrm{IgG2a} \mathrm{mAb}$ is hardly affected in C5-deficient DBA/2 mice as well as in $\mathrm{BALB} / \mathrm{c}$ mice depleted of $\mathrm{C} 3$ by the treatment with cobra venom factor $[31,48]$. These data thus indicate limited, if any, activation of complement by antiRBC autoantibodies in mice. However, non-complement-fixing IgM antibodies with diverse specificities have been described $[36,61]$, and the structure of the antigen appears to influence the capacity of $\operatorname{IgM}$ antibodies to fix and/or activate 
complement [14]. Therefore, it is possible that the limited activation of complement by anti-mouse RBC monoclonal autoantibodies may be related to the particular structure of the target autoantigen. In addition, it is known that the reaction of complement-binding antibodies with RBC does not always lead to complement activation. This is due to the activity of a number of complement-inhibitory proteins present on RBC membranes, and these regulatory proteins likely play an important role in preventing excessive damage to autologous cells. This would explain why the development of anemia caused by polyclonal rabbit IgG anti-mouse RBC antibodies, which are expected to activate complement, is hardly affected in mice genetically deficient in $\mathrm{C} 3$, but almost completely prevented in mice lacking both Fc $\gamma$ RI and Fc $\gamma$ RIII [51].

These results, however, cannot totally exclude a possible role of $\mathrm{C} 4$ in autoimmune hemolytic anemia, since the $\mathrm{C} 4 \mathrm{~b}$ fragment is recognized by complement receptors, which stimulate phagocytosis (for reviews, see $[1,6]$ ). In addition, in vivo clearance experiments of RBC sensitized with polyclonal rabbit $\lg \mathrm{G}$ anti-RBC antibodies in $\mathrm{C} 4$-deficient and control guinea pigs have shown that erythrophagocytosis can be mediated by the synergistic cooperation of $\mathrm{Fc} \gamma \mathrm{R}$ and complement receptors expressed on Kupffer cells [47]. Such a synergistic cooperation has also been demonstrated in a study using human peripheral blood monocytes in vitro [7]. This mechanism could be operative under certain conditions, depending on the extent of opsonization and the IgG isotypes of anti-RBC autoantibodies. In fact, our recent results suggest an additional role of complement in the accelerated development of anemia in mice receiving higher doses of the high-affinity $34-3 \mathrm{C}$ IgG2a mAb (manuscript in preparation). Clearly, more extensive analysis in C3- and C4-deficient mice in relation to the $\operatorname{IgG}$ isotypes of anti-RBC autoantibodies, their RBC-binding affinities and the extent of $\mathrm{RBC}$ opsonization could help to define more precisely the role of complement in the development of autoimmune hemolytic anemia.

In addition to autoimmune hemolytic anemia, the study with an IgG2a anti-platelet monoclonal autoantibody has also shown a minimal role of complement in immune elimination of platelets [51]. Moreover, it has been reported that $\mathrm{C} 3$ - and $\mathrm{C} 4$. deficient mice respond normally to the presence of pathogenic immune complexes by generating the Arthus reaction [51], in which FcyR-dependent activation of mast cells appears to be the major pathogenic mechanism [52]. In contrast, recent studies on such complement-deficient mice have clearly shown that complement is essential in innate immunity to bacterial pathogens, in which the interaction of natural IgM antibodies with bacteria apparently plays a critical role in the activation of the classical pathway of complement (for review, see [38]). On the basis of these findings, Ravetch and Clynes have proposed the following hypothesis: complement activation is essential in protection through natural $\mathrm{IgM}$ antibodies during innate immune responses, but not in immune-complex-triggered inflammation, while FcyR relay the action of IgG antibodies to effector cells and initiate the inflammatory cascade, thereby playing the dominant role in autoantibody-triggered autoimmune diseases. However, more recent studies have shown that complement is indeed required for the full-blown expression of immune-complex-mediated inflammatory reactions in several experimental models including the Arthus reaction, immune complex alveolitis and anti-glomerular basement membrane nephritis $[4,5,25,56]$. As discussed above, more extensive analysis in complement- or complement-receptor-deficient mice is awaited to elucidate what role complement really plays in autoantibody-triggered autoimmune cellular and tissue injuries. 


\section{Concluding remarks}

The use of four different anti-RBC IgG switch variants bearing identical variable regions has provided a unique opportunity to define the pathogenic potency of individual murine IgG isotypes in relation to the respective roles of high-affinity Fc $\gamma \mathrm{RI}$ and low-affinity F $c \gamma R$ III. Given the role of $F c \gamma R$ in phagocytosis, cellular cytotoxicity and release of inflammatory mediators by different types of inflammatory effector cells, it is important to understand the respective roles of the two different classes of activatory $F c \gamma R$, which interact differentially with individual IgG isotypes. Strikingly, the capacity of each IgG isotype to interact with the low-affinity Fo $\gamma$ RIII is the critical factor determining the pathogenic potency of individual $\mathrm{ggG}$ isotypes, while the high-affinity FcyRI apparently plays a relatively limited role, probably because of the competition with circulating monomeric IgG2a.

The demonstration of the highest pathogenic potency of the IgG2a isotype highlights the importance of the regulation of $\mathrm{IgG}$ isotype responses in both autoantibody-mediated diseases and immune-complex-mediated inflammatory disorders. A recent study has shown that FcyR-mediated inflammatory responses play an important role in the pathogenesis of lupus-like glomerulonephritis [10], supporting the possibility of a higher nephritogenic potential for autoantibodies of the IgG2a isotype. Although anti-RBC autoantibodies of the IgG3 isotype appear to be less pathogenic, nephritogenic activities of IgG3 autoantibodies have also been well established, on the basis of a cryoglobulin activity uniquely associated with the IgG3 heavy-chain constant region $[20,41\}$. These findings are consistent with the observation that the progression of murine lupus-like autoimmune syndrome is correlated with the relative dominance of $\mathrm{Th} 1$ autoimmune responses promoting the production of IgG2a and IgG3 autoantibodies $[3,45,53\}$. Clearly, further studies on the pathogenic role of autoantibodies of different Ig isotypes in relation with the Th subset response would help establish new strategies for the development of therapeutic approaches in autoantibody-mediated autoimmune diseases.

Acknowledgements. The studies from the authors' laboratory discussed in this review were supported by a grant from the Swiss National Foundation for Scientific Research.

\section{References}

1. Ahearn JM, Fearon DT (1989) Structure and function of the complement receptors of CR I (CD35) and CR2 (CD2 1). Adv Imrnunol 46:183

2. Amigorena S, Bonnerot C, Drake JR, Choquet D, Hunziker W, Guillet JG, Webster P, Sautes C, Mellman I, Fridman WH (1992) Cytoplasmic domain heterogeneity and functions of IgG Fc receptors in B lymphocytes. Science $256: 1808$

3. Balomenos D, Rumold R. Theofilopoulos AN (1998) Interferon- $\gamma$ is required for lupus-like disease and lymphoaccumulation in MRL-lpr mice. $J$ Clin Invest 101:364

4. Baumann U, Köhl J, Tschernig T, Schwerter-Strumpf K. Verbeek JS, Schmidr RE, Gessner JE (2000) A codominant role of FcyRL/III and CSaR in the reverse Arthus reaction. J Immunol 164:1965

5. Bozic CR, Lu B, Höpken UE, Gerard C, Gerard NP (1996) Neurngenic amplification of immune complex inflammation. Science 273:1722

6. Brown EJ (1991) Complement receptors and phagocytosis. Curr Opin Immunol 3:76

7. Brown EJ, Bohnsack JF, Gresham HD (1988) Mechanism of inhibition of immunoglobulin G-mediated phagocytosis by monoclonal antibodies that recognize the Mac-1 antigen. J Clin Invest $81: 365$ 
8. Cabral AR, Cabiedes J, Alarcon-Segovia D (1990) Hemolytic anemia related to an IgM autoantibody to phosphatidylcholine that binds in vitro to stored and to bromejain-treated human erythrocytes. J Autoimmun 3:773

9. Caultield MJ, Stanko D, Calkins C (1989) Characterization of the spontaneous autoimmune (antierythrocyte) response in NZB mice using a pathogenic monoclonal autoantibody and its anti-idiotype. Immunology 66:233

10. Clynes R, Dumitru C, Ravetch JV (1998) Uncoupling of immune complex formation and kidney damage in autoimmune glomerulonephritis. Science 279:1052

11. Clynes R, Maizes JS, Guinamard R, Ono M. Takai T, Ravetch JV (1999) Modulation of immune complex-induced inflammation in vivo by the coordinate expression of activation and inhibitory Fc receptors. J Exp Med 189:179

12. Clynes $R$, Ravetch JV (1995) Cytotoxic antibodies trigger inflammation through Fc receptors. Immunity $3: 21$

13. Cohen PL, Eisenberg RA (1991) Lpr and gld: single gene models of systemic autoimmunity and lymphoproliferation disease. Annu Rev Immunol 9:243

14. Cunniff RV, Stollar BD (1968) Properties of $19 \mathrm{~S}$ antibodies in complement fixation. 1. Temperature dependence and role of antigen structure. J Imınunol 100:7

15. Daeron M (1997) Fe receptor biology. Annu Rev Immunol 15:203

16. Diamond B, Yelton DE (1981) A new Fo receptor on mouse macrophages binding loG3. J Exp Med 153:514

17. Ernst LK, Duchemin AM. Anderson CL (1993) Association of the high-aftinity receptor for IgC (Fc $\gamma R I$ ) with the $\gamma$ subunit of the IgE receptor. Proc Natl Acad Sci USA 90:6023

18. Fossati-Jimack L, Ioan-Facsinay A. Reininger L, Chicheportiche Y, Watanabe N. Saito T, Holhuis FMA, Gessner JE, Schiller C. Schmidt RE. Honjo T, Verbeek JS, Izui S (2000) Markedly different pathogenicity of four IgG isotype-switch variants of an anti-erythrocyte autoantibody is based on their respective capacity to interact in vivo with the low-affinity FcyRIII J Exp Med 191:1293

19. Fossati-Jimack L, Reininger L, Chicheportiche Y, Clynes R, Ravetch JV, Honjo T, lzui S (1999) High pathogenic potential of low-affinity autoantibodies in experimental autoimmune hemolytic anemia. J Exp Med 190:1689

20. Fulpius T, Spertini F, Reininger L, Izui S (1993) Immunoglobulin heavy chain constant region determines the pathogenicity and the antigen-binding activity of theumatoid factor. Proc Natl Acad Sci USA 90:2345

21. Gavin AL, Barnes N, Dijstelhloem HM, Hogarth PM (1998) Identification of the mouse IgG3 receptor: implications for antibody effector function at the interface between innate and adaptive inmunity. I Imnunol 160:20

22. Grabar P (1983) Autoantibodies and the physiological role of immunoglobulins. Immunol Today 4:337

23. Heusser CH, Anderson CL, Grey HM (1977) Receptors for IgG: subciass specificity of receptors on different mouse cell types and the definition of two distinct receptors on a macrophage cell line. J Exp Med 145:1316

24. Hirose S, Wakiya M, Kawano-Nishi Y, Yi J, Sanokawa R. Taki S, Shimamura T, Kishimoto T, Tsurui $H$, Nishimura $H$, Shirai $\Upsilon$ (1993) Somatic diversification and affinity maturation of IgM and $\operatorname{lgG}$ antiDNA antibadies in mutine lupus. Eur J Immunol 23:2813

25. Höpken UE, Lu B, Gerard NP, Gerard C (1997) Inpaired inflammatory responses in the reverse Arthus reaction through genetic deletion of the C5a receptor. J Exp Med 186:749

26. Howie JB, Helyer BJ (1968) The immunology and pathology of NZB mice. Adv Immunol 9:215.

27. Hulett MD, Hogath PM (1994) Molecular basis of Fc receptor function. Adv Inmumol 57:1

28. Hulett MD, Osman N, McKenzie IFC. Hogarth PM (1991) Chimeric Fo receptors identify functional domains of the murine high affinity receptor for IgG. J Immunol 147:1863

29. Jacobson BA. Sharon J, Shan H, Shlomchik M, Weigert MG, Marshak-Rothstein A (1994) An isotype switched and somatically mutated rheumatojd factor clone isolated from a MRL-Ipr/lpr mouse exhibits limited intraclonal affinity maturation. J Immunol 152:4489

30. Linder E. Edgington TS (1972) Antigen specificity of anti-erythrocyte autoantibody responses of NZB mice: identification and partial characterization of two erythrocyte surface autoantigens. I Immunol 108: 1615

31. Meyer D, Schiller C, Westermann J, Izui S, Hazenbos WLW, Verbeek JS, Schmidt RE, Gessner JE (1998) FcrRIII (CD16)-deficient mice show IgG isotope-dependent protection to experimental autoimmune hemolytic anemia. Blood 92:3997 
32. Miller KL, Duchemin AM, Anderson CL (1996) A novel role for the Fc receptor $\gamma$ subunit: enhancement of FcrR ligand affinity. J Exp Med 183:2227

33. Murakami M, Nakajima K. Yamazaki K-I, Muraguchi T, Serikawa T, Honjo T (1997) Effects of breeding environments on generation and activation of autoreactive B-1 cells in anti-red blood cell autoantibody transgenic mice. J Exp Med 185:791

34. Murakami M, Tsubata T, Shinkura R, Nisitani S. Okanoto M, Yoshioka H, Usui T, Miyawaki S. Honjo T (1994) Oral administration of lipopolysaccharides activates B-1 cells in the peritoneal cavity and lamina propria of the gut and induces autoimmune symptoms in an autoantibody transgenic mouse. J Exp Med 180:111

35. Ono M, Okada H, Boooand S, Yanagi S, Kurosaki T, Ravetch JV (1997) Deletion of SHIP of SHP-1 reveals two distinct pathways for inhibitory signaling. Cell 90:293

36. Plotz PH, Colten H, Tala N (1968) Mouse macroglobulin antibody to sheep erythrocytes: a non-compleinent-fixing type. J Immunol 100:752

37. Ravetch JV (1994) Fc receptors: rubor redux. Cell 78:553

38. Ravetch JV, Clynes RA (1998) Divergent roles for Fc recptors and complement in vivo. Annu Rev Immunol 16:421

39. Ravetch JV, Kinet JP (1991) Fc receptors. Annu Rev Immunol 9:457

40. Ravetch JV, Luster AD, Weinshank R, Kochan J, Pavlovec A, Portnoy DA. Hulmes J, Pan Y-CE, Unkeless JC (1986) Structural heterogeneity and functional domains of murine inmunoglobulin $G \mathrm{Fc}$ receptors. Science $234: 718$

41. Reininger L, Bemey T, Shibata T, Spertini F, Merino R, Izui S (1990) Cryoglobulinemia induced by a murine IgG3 sheumatoid factor: Skin vasculitis and glomerulonephritis arise from distinct pathogenic mechanisms. Proc Natl Acad Sci USA 87:10038

42. Reininger L, Radaszkiewicz T, Kosco M, Melchers F, Rolink AG (1992) Development of autoimmune disease in SCID mice populated with long-term in vitro proliferating (NZB $\times$ NZW)Fl pre-B cells. J Exp Med 176:1343

43. Reininger L, Winkler TH, Kalbeter CP, Jourdan M, Melchers F, Rolink AG (1996) Intrinsic B cell de fects in NZB and NZW mice contribute to systemic lupus erythematosus in (NZB $x$ NZW)F1 mice. J Exp Med 184:853

44. Samuelsson A, Towers TL, Ravetch JV (2001) Anti-inflammatory activity of IVIG mediated through the inhibitory receptor. Science 291:484

45. Santiago ML, Fossati L. Jacquet C, Müller W, Izui S, Reininger L (1997) Interleukin-4 protects against a genetically linked lupus-like autoimmune syndrome. J Exp Med 185:65

46. Schiller C, Janssen-Graalfs I, Baumann U, Schwerter-Strumpf K, Izui S, Takai T, Schmidt RE. Gessner JE (1999) Mouse FcyRII is a negative regulator of FcyRIII in IgG immune complex triggered intlammation but not in autoantibody induced hemolysis. Eur J Immunol 30:481

47. Schreiber AD, Frank MM (1972) Role of antibody and complement in the immune clearance and de struction of erythracytes. I. In vivo effects of $\mathrm{IgG}$ and $\operatorname{lgM}$ complement-fixing sites. J Clin Invest $51: 575$

48. Shibata T, Berney T, Reininger L. Chicheportiche Y, Ozaki S, Shirai T, Izui S (1990) Monoclonal antierythrocyte autoantibodies derived from NZB mice cause autoimmune hemolytic anemia by two dis tinct pathogeric mechanisms. Int Immunol 2:1133

49. Shlomchik M, Mascelli M. Shan H, Radic MZ, Pisetsky DS, Marshak-Rothstein A, Weigert M (1990) Anti-DNA antibodies from autoimmune mice arise by clonal expansion and somatic mutation. $J$ Exp Med 171:265

50. Snapper CM, Mond JJ (1993) Towards a comprehensive view of immunoglobulin class switching. Immunol Today $14: 15$

51. Sylvestre DL, Clynes R, Ma M, Warren H, Carroll MC, Ravetch JV (1996) Immunoglobulin G-mediated inflammatory responses develop normally in complement deficient mice. J Exp Med 184:2385

52. Sylvestre DL, Ravetch JV (1996) A dominant role for mast cells $F \mathcal{C}$ receptors in the Arthus reaction. Immunity 5:387

53. Takahashi S, Fossati L, Iwamoto M, Merino R, Motta R, Kobayakawa T, Izui S (1996) Imbalance towards $T h 1$ predominance is associated with acceleration of lupus-like autoimmune syndrome in $M R L$ mice. J Clin Invest 97:1597

54. Takai T, Li M, Sylvestre D, Clynes R, Ravetch JV (1994) FcR y chain deletion results in pleiotrophic effeclor cell defects. Cell 76:519

55. Takai T, Ono M, Hikida M. Ohmori H, Ravetch JV (1996) Augmented humoral and anaphylactic re sponses in FcyRlI-deticient mice. Nature 379:346 
56. Tang T, Rosenkranz A, Assmann KJM, Goodman MJ, Gutierrez-Ramos JC, Carroll MC, Cotran RS, Mayadas TN (1997) A role of Mac-1(CD1/b/CD18) in immune complex-stimulated neutrophil function in vivo: Mac-1 deficiency abrogates sustained Fcg receptor-dependent neutrophil adhesion and complement-dependent proteinuria in acute glomenionephritis. J Exp Med 186:1853

57. Tillman DM, Jou N-T, Hill RJ, Marion TN (1992) Both IgM and IgG anti-DNA antibodies are the products of clonally selective $B$ cell stimulation in $(\mathrm{NZB} \times \mathrm{NZW}) \mathrm{Fl}$ mice. J Exp Med 176:761

58. Tsubata T, Murakami M, Honjo T (1994) Antigen-receptor cross-linking induces peritoneal B-cell apoptosis in normal but not autoimmunity-prone mice. Curr Biol 4:8

59. Ujike A, Ishikawa Y, Ono M, Yuasa T, Yoshino T, Fukumoto M, Ravetch JV, Takai T (1999) Modulation of immunoglobulin (Ig)E-mediated systemic anaphylaxis by low-affinity Fc receptors for IgG. J Exp Med 189:1573

60. Unkeless JC, Eisen $\mathrm{HN}$ (1975) Binding of monomeric immunoglobulins to $\mathrm{Fc}$ receptors of mouse macrophages. J Exp Med 142:1520

61. Van Snick JL, Masson P (1978) The effects of complement on the ingestion of soluble antigen-antibody complexes and IgM aggregates by mouse peritoneal macrophages. J Exp Med 148:903

62. Weinshank RL, Luster AD, Ravetch JV (1988) Function and regulation of a murine macrophage-specific IgG Fc receptor, Fc $\gamma$ R- $\alpha$. J Exp Med 167:1909

63. Yuan R, Clynes R, Ravetch JV, Scharff MD (1998) Antibody-nediated modulation of Cryprococcus neoformans infection is dependent on distinct $F c$ receptor functions and IgG subclasses. J Exp Med 187:641 